\title{
İş Yaşam Dengesi Üzerine Bir Araştırma: Lisansüstü Tezlerin Bibliyometrik Analizi (A Research on Work-Life Balance: A Bibliometric Analysis of Postgraduate Thesis )
}

\author{
Mecbure ASLAN iD a
}

a Kahramanmaraş Sütçü İmam Üniversitesi, Kahramanmaraş, Türkiye. mecbureaslan@ksu.edu.tr

\begin{tabular}{|c|c|}
\hline MAKALE BİLGİSİ & ÖZET \\
\hline Anahtar Kelimeler: & Amaç - İş yaşamındaki değişimler, örgütsel yapılardaki farklılaşmalar, teknolojik değişimler, iş ve yaşamın \\
\hline İş Yaşam Dengesi & diğer alanlarındaki etkileşimin iş yaşamına etkisi, dijitalleşme ve çalışma zamanlarına ilişkin farklı \\
\hline Bibliyometrik Analiz & uygulamalar, çalışanların iş ve diğer yaşam alanları arasındaki dengeyi sağlamaları gerekliliğini giderek \\
\hline Lisansüstü Tezler & $\begin{array}{l}\text { arttırmaktadır. Yoğun iş yaşamı ve işin yaşam alanı içerisinde geniş bir yer kaplaması, iş yaşam dengesinin } \\
\text { özellikle son yıllarda birçok araştırmaya konu olmasını sağlamaktadır. Bu araştırmanın amacı iş yaşam } \\
\text { dengesi odaklı Ulusal Tez Merkezi internet sitesinde yayınlanan lisanüstü tezlerin bibliyometrik analizini }\end{array}$ \\
\hline
\end{tabular}

Gönderilme Tarihi 25 Haziran 2021 Revizyon Tarihi 20

Ağustos 2021

Kabul Tarihi 30 Ağustos 2021

Makale Kategorisi: Araştırma Makalesi
Yöntem - Araştırma kapsamında Yüksek Öğretim Kurumu Ulusal Tez Merkezi veri tabanından 2021 Mayıs ayında tarama terimi olarak iş yaşam dengesi terimi girilmiştir. Ulaşılan lisansüstü tezlerin bazı değişkenler açısından bibliyometrik analizleri yapılmıştır.

Bulgular - Ulusal Tez Merkezi veri tabanından iş yaşam dengesi terimiyle tarama yapılmış ve 70 adet teze ulaşılmıştır. Araştırma kapsamında 70 adet tez; tez adı, yılı, türü, yayınlandığı yıl, dili, danışman ünvanı, üniversite, enstitü, anabilim dalı, araştırma yöntemi, veri toplama araçları, anahtar kelimeler ve özet gibi değişkenler açısından incelenmiştir. Araştırrma kapsamında tezlerin çoğunluğunun 2019 yılında ve yüksek lisans tezlerinden oluştuğu görülmektedir. 2007 yılından itibaren yapılmış tezlere ulaşılmıştır. Lisansüstü tezlerin daha çok işletme ana bilim dalında yoğunlaştı̆̆ı görülmektedir.

Tartışma - İş yaşam dengesi terimiyle Ulusal Tez Merkezi internet sayfasından taranan 70 adet lisansüstü tez bibliyometrik analizle incelenmiștir. İş yașamı, genel yașam alanında geniș bir yer kaplamakta olup, iș yaşamının diğer yaşam alanlarını etkilediği, yaşamın diğer alanlarının da iş yaşamını etkilediği görülmektedir. İş ve diğer yaşam alanları arasındaki dengenin sağlanması giderek daha önemli hale gelmektedir. Bu bağlamda iş yaşam dengesinin daha fazla araştırmaya konu olmasının ve farklı değişkenlerle ele alınmasının literatüre, araştırmacılara, öğrencilere ve uygulayıcılara katkı sağlayacağı düşünülmektedir.

ARTICLE INFO ABSTRACT

\section{Keywords:}

Work Life Balance Bibliometric Analysis Postgraduate Theses

Received 25 June 2021 Revised 20 August 2021 Accepted 30 August 2021

Article Classification: Research Article
Purpose - Changes in business life, differentiations in organizational structures, technological changes, the effect of interaction in work and other areas of life on business life, digitalization and different practices related to working times increase the need for employees to maintain a balance between work and other life areas. The busy work life and the fact that the work occupies a large place in the living space makes the worklife balance the subject of many researches, especially in recent years. The aim of this research is to make a bibliometric analysis of postgraduate theses published on the website of the National Thesis Center focused on work-life balance and to examine the issue of work-life balance from the perspective of the thesis studies.

Design/methodology/approach - Within the scope of the research, the term work-life balance was entered as a search term in May 2021 from the Higher Education Institution National Thesis Center database. Bibliometric analyzes of the obtained postgraduate theses were made in terms of some variables.

Findings - The database of the National Thesis Center was searched with the term work-life balance and 70 theses were reached. Within the scope of the research, 70 theses; The thesis was examined in terms of variables such as name, year, type, year of publication, language, title of advisor, university, institute, department, research method, data collection tools, keywords and abstract. Within the scope of the research, it is seen that the majority of theses are in 2019 and consist of master's theses. Theses made since 2007 have been reached. It is seen that graduate theses are mostly concentrated in the Department of Business Administration.

Discussion - 70 postgraduate theses scanned from the website of the National Thesis Center with the term work-life balance were analyzed by bibliometric analysis. Business life occupies a large place in the general living area, and it is seen that business life affects other living areas, and other areas of life affect business life. Maintaining a balance between work and other areas of life is becoming more and more important. In this context, it is thought that making work-life balance the subject of more research and dealing with different variables will contribute to the literature, researchers, students and practitioners. 


\section{GİRISs}

İş yaşamı bireylerin yaşamının çok büyük bir alanını kapsamaktadır. İş yaşamındaki değişiklikler, örgütsel yapıların değişmesi, teknolojik değişimler, hastalıklar, yaşamın genelindeki değişimler, artan ihtiyaçlar gibi nedenlerle iş yaşamı ve yaşamın diğer alanları arasında denge sağlamak daha önemli hale gelmektedir. İş yaşam dengesi, bireyin çalışma yaşamı, aile yaşamı ve yaşamın diğer alanlarındaki sorumlulukları, faaliyetleri yerine getirebilmesidir (Delecta, 2011:186). İş yaşam dengesi kavramı, iş yaşamı ile kişisel yaşamın birbirinin tamamlayıcısı olarak görülmesidir (Syed, 2015:288). İş ve diğer yaşam alanları arasındaki çatışmaların azaltılarak uyumun yakalanması olarak ifade edilmektedir. Toplumda meydana gelen değişiklikler, hem işte hem de evde önemli sorumlulukları olan bireylerin sayısını arttırırken, iş ve ev hayatı arasındaki karşılıklı bağımlılıklar hakkında daha fazla araştırma yapılmasını da hızlandırmıştır (Clark, 2000:749).

İş yaşam dengesi, batı bağlamında zamana bağlı olarak ortaya çımıştır. Yönetimle ilgili ikilemler, ücretli iş, hayatın diğer bölümleri ve özellikle aile araştırmaların odak noktası olmuştur. Örneğin 1960'lardan itibaren işgücüne giren kadın sayısı artmıştır. Belirli bağlamlardaki araştırmalar çalışan anneler ve çift gelirli ailelere odaklanma eğilimindeydi. 1980 ve 1990'larda iş yerindeki değişiklikler stres ve tükenmişlikle ilgili endişeler ve iş aile çatışmaları araştırmalara yansımıştır (Lewis, 2007:360). İş yaşam dengesi günümüzde hala önemli bir araştırma konusu olarak karşımıza çıkmaktadır. İş yaşam dengesi hem iş hem yaşamın diğer alanları arasındaki uyumun sağlanmasına odaklanırken birçok değişkenle etkileşim halinde bulunmaktadır. Farklı değişkenler ile ilişkisi ve etkileşimi olan iş yaşam dengesinin hem bireyler hem örgütler için önemli olduğu görülmektedir.

Çalışanların iş yaşam dengelerini oluşturabilmesi, hem işlerinden tatmin olmasını hem de özel ve aile yaşamlarından tatmin olmasını sağlayabilecektir. İş yaşam dengesini sağlayan çalışanların, performansının yüksek olması ve çalıştıkları örgütlere bağlılıklarının da yüksek olması beklenebilir. Bu denge örgütlerin de performaslarına olumlu katkı sağlayacaktır. İş yaşam dengesi çalışanlar, örgütler ve diğer bireyler açısından oldukça önemli bir konu olarak karşımıza çıkmaktadır. Bu araştırmanın amacı iş yaşam dengesine ilişkin Türkiye'de belirli dönemde yapılan lisansüstü tezlerin bibliyometri yöntemiyle incelenmesidir. Yapılan araştırmanın literatüre, araştırmacılara, öğrencilere ve uygulayıcılara katkı sağlayacağı düşünülmektedir.

\section{KAVRAMSAL ÇERÇEVE}

Yaşam alanı içerisinde bireyin farklı rolleri bulunmaktadır. İş yaşamı bireyin genel yaşamı içerisinde çok büyük bir alanı oluşturmaktadır. Örgütlerin yapısındaki değişimler, iş yaşamının hareketliliği, teknolojik gelişmeler, değişen dengeler, hastalıklar bireyin iş ve diğer yaşam alanları arasında uyum sağlamasını daha da önemli hale getirmektedir.

Denge kavramı ağırlık ve miktar olarak eşit dağılma anlamına gelmekle birlikte dengenin fiziksel ve psikolojik bir anlam taşıdığı, hem nesnel hem öznel anlam ve ölçümü olabileceği, koşullara ve bireylere göre değişebileceğini kabul etme ihtiyacını doğurmaktadır (Guest, 2002:261). İş yaşam dengesi bireyin iş ve bireysel yaşam talepleri arasında dengenin sağlanmasıdır (Lockwood, 2003:2). Dengeyi sağlamanın amacı öznel ve nesnel olarak yaşam kalitesini korumak ve arttırmaktır. İş yaşam dengesinin öznel boyutu iş ve yaşam memnuniyetini, nesnel boyutu ise sağlık, kariyer ve özel yaşamdaki başarıyı ifade etmektedir (Hildebrandt, 2006:255-256). İş yaşam dengesi, iş ve aile yaşamındaki rollere ilişkin beklentilerin karşılanmasıdır (Grzywacz ve Carlson, 2007:458; Brough vd., 2020:3). Ayrıca bireyin enerjisini, sorumluluklarını ve zamanını yaşam alanı içerisinde eşit olarak dağıtması iş yaşam dengesi (Kirchmeyer 2000; Brough vd., 2020:2) olarak ifade edilmektedir. İş ve diğer yaşam alanları arasındaki enerji, zaman ve sorumlulukların dağılımı, bireylere ve koşullara göre değişkenlik gösterebilir. Dolayısıyla iş ve diğer yaşam alanları arasında enerji, zaman ve sorumlulukların eşit ve etkin dağılımını sağlamak için iş yaşam programlarına ihtiyaç duyulmaktadır.

İş yaşam dengesi 1980'lerin ikinci yarısında ortaya çıkan bir terim olmakla birlikte iş yaşam programları 1930'lara kadar uzanmaktadır (Lockwood, 2003:2). İş yaşam programları, bir işveren tarafından oluşturulan programlar (genellikle finansal veya zamanla ilgili) çalışanların iş ve kişisel sorumluluklarını ele alma seçenekleridir. Bu programlar önceleri çocuklu kadınları desteklemek amacıyla uygulanmaya başlanmış, daha sonraları bireylerin tüm yaşam alanlarına göre hazırlanmıştır. Günümüzde çalışanlar, işletmelerin kontrollü olmakla birlikte esneklik sağlamasını da beklemektedirler (Dhas ve Karthikeyan, 2015:11). İş yaşam programları, çalışanların moralini yükseltmek, devamsızlığı azaltmak, örgütsel bilgiyi korumak ve özellikle zor ekonomik zamanlarda önemli potansiyele sahiptir. Çalışanlar, iş arkadaşları, aileler, çift kariyerli eşler, 
örgütler için iş yaşam programları gerekmektedir (Lockwood, 2003:9). İş yaşam programlarının etkinliğini arttırabilmek için iş yaşam dengesini etkileyen unsurları bilmek gerekmektedir.

İş yaşam dengesini etkileyen etmenler, bireysel ve örgütsel etmenler olarak sinıflandırılabilir. Bireysel etmenler arasında işe yönelim, kişilik, kişisel kontrol, cinsiyet, yaş, yaşam ve kariyer sıralanabilir. Örgütsel etmenler arasında ise iş talepleri, iş kültürü, iş dışındaki yaşam talepleri, iş dışı kültür yer almaktadır (Guest, 2002:265). Bireysel ve örgütsel etmenler, iş yaşam dengesini olumlu ya da olumsuz bir şekilde etkileyebilir. Farklı bireyler, örgütler ve koşullarda bu faktörlerin etki oranı değişiklik gösterebilir. Ayrıca iş yaşam dengesinin sağlanabilmesi veya sağlanamaması farklı bireysel ve örgütsel sonuçlar doğurmaktadır. Bu sonuçlar arasında iş doyumu, yaşam doyumu, zihinsel sağlık, iyi oluş, stres, hastalık, iş davranışı ve performansı, iş dışı yaşam davranışı ve performansı, işyerindeki diğer insanlarla etkileşim ve iş dışı yaşamda diğer insanlarla etkileşim yer almaktadır (Guest, 2002:265).

İş ve iş dışındaki yaşam arasındaki etkileşim farklı kuramlarla incelenebilir (O,Driscoll, 1996). Ancak iş yaşam dengesini en iyi açılayan kuramlardan biri Taşma (Yayılma) Kuramıdır. Taşma (Yayılma) Kuramı'na göre yaşamın bir alanındaki olumlu ve olumsuz deneyimler yaşamın diğer alanlarını etkilemektedir. Farklı yaşam alanları geçirgen özelliğe sahiptir. Yaşamın herhangi bir alanındaki yaşananlar diğer yaşam alanlarına yayılmaktadır. Bireyin iş yaşamındaki tutum ve davranışları diğer yaşam alanlarını, diğer yaşam alanlarındaki tutum ve davranışları iş yaşamını etkilemektedir (Dolan ve Gosselin, 1998:1). Yaşam alanları arasındaki bu yayılma olumlu ya da olumsuz olabilir. Negatif yayılma, iş ve ev yaşamının birinde yaşanan olumsuz deneyimlerin diğer alanı da olumsuz yönde etkilemesidir. Pozitif yayılma ise iş ve ev yaşamı arasında olumlu deneyimlerin taşmasıdır. Bir yaşam alanındaki becerilerin, yeteneklerin, değerlerin ve duyguların olumlu olarak diğer yaşam alanına aktarılmasıdır. Negatif yayılma düşük iş tatmini, düşük örgütsel bağlılık, işten ayrılma niyeti, gecikme ve devamsızlık, performansın düşmesi, fiziksel ve psikolojik iyi oluşun azalması gibi sonuçları beraberinde getirmektedir. Pozitif yayılma iş tatminini, bağlılığı, fiziksel ve zihinsel sağlığı olumlu etkilemektedir (Sok vd., 2014:459). Yayılma kuramı, bireyin yaşamının bir alanındaki tatminin diğer alanlara da yayıldığını öne sürer. $\mathrm{Bu}$, yaşamdan iş doyumuna ya da işten yaşam doyumuna olabilir (Iverson ve Maguire, 2000:4). Yaşamın bir alanında yaşanan olumsuzluklar veya olumlu deneyimler diğer yaşam alanlarına taşmakta olup iş yaşamı diğer yaşam alanlarını etkilemektedir. Yaşamın diğer alanlarındaki deneyimler de iş yaşamını etkilemektedir. Yaşam alanları arasında olumlu deneyim, bilgi, beceri, yetenek ve duyguların aktarılması iş yaşamı ve diğer yaşam alanlarını olumlu etkileyerek iş yaşam dengesini daha kolay sağlayabilecektir.

İş yaşamı, özel yaşam, aile yaşamı, boş zaman bireyin yaşam alanları içerisinde yer alırken bunlar arasında uyum sağlanması bireyin işinden ve genel yaşamından memnuniyetini arttırabilecektir. İş yaşam dengesinin sağlanmasında bireylerin planlı çalışması, zamanlarını doğru değerlendirmesi, iş arkadaşları ve aile bireyleriyle iş bölümü yapması, yapılacak işlerini ertelememesi önemli görülmektedir. Ayrıca örgütlerin doğru işe doğru işgören almaları, iş yükünü adil dağıtmaları, esnek çalışma, kısmi çalışma ya da uzaktan çalışma uygulamaları, süreki eğitim, motive edici etkinlikler ve yönetici davranışlarının iş yaşam dengesinin sağlanmasında önemli olduğu söylenebilir.

\section{YÖNTEM}

Bu bölümde araştırmanın modeli, evren ve örneklemi, veri toplama süreci ve veri analiz süreci hakkında bilgi sunulmuştur.

\subsection{Araştırma Modeli}

Araştırmada tarama modeli kullanılmıştır. Araştırmanın temel amacı, iş yaşam dengesi kavramına ilişkin yapılan lisansüstü tezlerin farklı değişkenler açısından incelenmesidir. Tarama modelleri, araştırmaya dahil edilen deneklerin belirli konulardaki özellik ve tutumlarının tespit edidiği araştırmalardır (Gürbüz ve Şahin, 2014:103).

\subsection{Araştırmanın Evreni ve Örneklemi}

Çalışmaya araştırma döneminde ulaşılan tüm tezler dahil edilmiştir. YÖK Ulusal Tez Merkezi veri tabanı esas alınarak 2021 Mayıs ayında iş yaşam dengesi terimi ile tarama yapılmıştır. Bu tarihe kadar yayınlanan 70 adet lisansüstü teze ulaşılmıştır. Araştırmada 58 adet yüksek lisans ve 12 adet doktora tezine ulaşılmıştır. 


\subsection{Veri Kaynaklarn ve Veri Toplama Aracı}

Ulaşılan tez çalışmalarının bibliyometrik analizlerinin yapılması için tez künyelerinden yararlanılmıştır. Tezler, tez künyelerindeki "yayınlandığı yıl", "tezin dili", "danışman ünvanı", "yayınlandığı üniversite", "yayınlandığı enstitü", yayınlandığı ana bilim dalı", "araştırma yöntemi", "araştırmada kullanılan veri toplama araçları", "anahtar kelimeler" ve "tez özeti" değişkenleri açısından incelenmiştir. Tezlere ilişkin veriler sınıflandırılarak sistematik bir form oluşturulmuştur.

\subsection{Verilerin Analizi}

Tezlerin incelenmesinde MAXQDA 2020 programı kullanılmıştır. Tanımlayıcı istatistikler, frekans, çapraz tablolar ve nicel içerik analizi yapılarak, bibliyometrik analiz yöntemiyle tüm tezler değerlendirilmiştir. Pritchard bibliyometriyi, yazılı iletişim süreçlerine, bir disiplinin gelişiminin doğasına ve seyrine ışık tutmak, yazılı iletişimin çeşitli yönlerini saymak, analiz etmek yoluyla matematiksel ve istatistiksel yöntemlerin uygulanması olarak tanımlamaktadır (Lawani, 1981:294). Bibliyometrik analiz, bir araştırma konusunda nitel ve nicel değişiklikleri belirlemek, bir araştırma konusuyla ilgili yayınların profilini oluşturmak ve belirli bir bilimsel alandaki eğilimleri tespit etmek amacıyla istatistiksel yöntemlerin uygulanması ile ortaya konulan analiz çeşididir (De Bakker vd., 2005; Marti vd., 2016:1652). Bibliyometrik analizin kitaplar, makaleler, tezler ve araştırma konularına yönelik olarak matematiksel ve istatistiksel yöntemlerden yararlanarak yapılan bir analiz olduğu görülmektedir. Böyle bir analiz yöntemi incelenen yayınlara ilişkin araştırmacılara veya uygulayıcılara faydalı çıktılar sağlamaktadır.

\section{BULGULAR}

Araştırma bulguları kapsamında tezler, tez künyelerindeki "yayınlandığı yıl", "tezin dili", "danışman ünvanı", "yayınlandığı üniversite", "yayınlandığı enstitü", "yayınlandığı ana bilim dalı", "araştırma yöntemi", "araştırmada kullanılan veri toplama araçları", "anahtar kelimeler" ve "tez özeti" değişkenleri açısından analiz edilerek elde edilen veriler tablolar, şekiller ve grafiklerden yararlanılarak sunulmuştur.

Yapılan araştırmada 70 adet lisansüstü teze ulaşılmıştır. Tezlerin 58 adetinin $(\%$ 82,9) yüksek lisans ve 12 adetinin $(\%$ 12,1) doktora tezi olduğu tespit edilmiştir. Lisansüstü tezlerin hangi enstitüye bağlı olarak yapıldığ edilmiştir. Ayrıca taranan tezlerden sadece 1 adeti İngilizce olup, 69 adeti Türkçedir.

Tablo 1'de tezlerin üniversitelere göre dağılımı yer almaktadır. Tablo 1' de tezin yapıldığı üniversiteler sayı ve yüzde olarak verilmiştir. Muğla Sıtkı Koçman Üniversitesi 6 adet tez ile ilk sırada yer almaktadır. İlk sıradaki Muğla Sıtkı Koçman Üniversitesi'ni Bahçeşehir, İstanbul, Marmara, Akdeniz, Dokuz Eylül ve Kütahya izlemektedir.

Tablo 1. Tezlerin Üniversitelere Göre Dağılımı

\begin{tabular}{|l|l|l|l|l|l|}
\hline Tezin yayınlandığı üniversite & $\begin{array}{l}\text { Frekans } \\
\text { (Sıklık) }\end{array}$ & Yüzde & Tezin yayınlandığı üniversite & $\begin{array}{l}\text { Frekans } \\
\text { (Sıklık) }\end{array}$ & Yüzde \\
\hline $\begin{array}{l}\text { Muğla Sıtkı Koçman } \\
\text { Üniversitesi }\end{array}$ & 6 & 8,57 & $\begin{array}{l}\text { Nevşehir Hacı Bektaş Veli } \\
\text { Üniversitesi }\end{array}$ & 1 & 1,43 \\
\hline Bahçeşehir Üniversitesi & 5 & 7,14 & Karadeniz Teknik Üniversitesi & 1 & 1,43 \\
\hline İstanbul Üniversitesi & 4 & 5,71 & Niğde Ömer Halisdemir Üniversitesi & 1 & 1,43 \\
\hline Marmara Üniversitesi & 4 & 5,71 & Çanakkale Onsekiz Mart Üniversitesi & 1 & 1,43 \\
\hline Akdeniz Üniversitesi & 3 & 4,29 & $\begin{array}{l}\text { Kırgızistan-Türkiye Manas } \\
\text { Üniversitesi }\end{array}$ & 1 & 1,43 \\
\hline Dokuz Eylül Üniversitesi & 3 & 4,29 & İstanbul Okan Üniversitesi & 1 & 1,43 \\
\hline $\begin{array}{l}\text { Kütahya Dumlupınar } \\
\text { Üniversitesi }\end{array}$ & 3 & 4,29 & Ylldız Teknik Üniversitesi & 1 & 1,43 \\
\hline İstanbul Aydın Üniversitesi & 2 & 2,86 & Bayburt Üniversitesi & 1 & 1,43 \\
\hline Kocaeli Üniversitesi & 2 & 2,86 & Yüzüncü Yıl Üniversitesi & 1 & 1,43 \\
\hline Hacettepe Üniversitesi & 2 & 2,86 & İzmir Katip Çelebi Üniversitesi & 1 & 1,43 \\
\hline Bursa Uludağ Üniversitesi & 2 & 2,86 & Ondokuz Mayı Üniversitesi & 1 & 1,43 \\
\hline
\end{tabular}


M. Aslan 13/3 (2021) 2623-2633

\begin{tabular}{|l|l|l|l|l|l|}
\hline Sakarya Üniversitesi & 2 & 2,86 & Mersin Üniversitesi & 1 & 1,43 \\
\hline İstanbul Arel Üniversitesi & 2 & 2,86 & $\begin{array}{l}\text { Burdur Mehmet Akif Ersoy } \\
\text { Üniversitesi }\end{array}$ & 1 & 1,43 \\
\hline Selçuk Üniversitesi & 2 & 2,86 & Afyon Kocatepe Üniversitesi & 1 & 1,43 \\
\hline Kırklareli Üniversitesi & 2 & 2,86 & Kastamonu Üniversitesi & 1 & 1,43 \\
\hline Hasan Kalyoncu Üniversitesi & 2 & 2,86 & Yalova Üniversitesi & 1 & 1,43 \\
\hline KTO Karatay Üniversitesi & 1 & 1,43 & Türk Hava Kurumu Üniversitesi & 1 & 1,43 \\
\hline Kırıkkale Üniversitesi & 1 & 1,43 & İstanbul Sabahattin Zaim Üniversitesi & 1 & 1,43 \\
\hline $\begin{array}{l}\text { Sakarya Uygulamalı Bilimler } \\
\text { Üniversitesi }\end{array}$ & 1 & 1,43 & Ankara Üniversitesi & 1 & 1,43 \\
\hline Ege Üniversitesi & 1 & 1,43 & Çukurova Üniversitesi & 1 & 7,43 \\
\hline & & & TOPLAM & 70 & 100,00 \\
\hline
\end{tabular}

Yukarıda Tablo 1'de görüldüğü üzere iş yaşam dengesi konusuna ilişkin tezlerin çeşitli üniversitelerde yapılmış olması konunun yaygınlığını, önemini ve araştırmacıların ilgisini çektiğini göstermektedir.

Tablo 2. Tezlerde Kullanılan Araştırma Yöntemleri

\begin{tabular}{|l|c|c|}
\hline Tezlerde kullanılan araştırma yöntemleri & Frekans (S1klık) & Yüzde \\
\hline Nicel & 60 & 85,7 \\
\hline Nitel & 4 & 5.7 \\
\hline Karma & 1 & 1,4 \\
\hline Derleme & 5 & 7,1 \\
\hline TOPLAM & 70 & 100 \\
\hline
\end{tabular}

Tezlerde kullanılan araştırma yöntemleri nicel, nitel, karma ve derleme olarak sınıflandırılmıştır. Araştırma yöntemi bu kategoriler içerisinde doğrudan belirtilmeyen tezlerde, sadece anket uygulanan tezler, anket ya da ölçek kullanıldığı belirtilen tezler nicel kategoride değerlendirilirken, ikincil veriler taranarak yapılan tezler derleme kategorisinde değerlendirilmiştir. Ayrıca nitel ve nicel yöntem beraber kullanılan tezlerde yöntem karma yöntem olarak kategorize edilmiştir.

Tablo 2' de görüldüğü üzere tezlerde kullanılan araştırma yöntemeleri incelendiğinde 70 adet tezin 60 (\% 85,7) adetinde nicel araştırma yöntemi kullanıldığı tespit edilmiştir.

Tablo 3. Tezlerde Kullanılan Veri Toplama Araçları

\begin{tabular}{|l|c|c|}
\hline Tezlerde kullanılan veri toplama araçları & Frekans (S1klık) & Yüzde \\
\hline Anket & 59 & 84,3 \\
\hline Görüşme & 4 & 5,7 \\
\hline Görüşme - Anket & 1 & 1,4 \\
\hline İkincil veriler & 6 & 8,6 \\
\hline TOPLAM & 70 & 100 \\
\hline
\end{tabular}

İş yaşam dengesi terimiyle taranan lisansüstü tezlerin çoğunluğunun nicel araştırma yöntemiyle yapıldığ1 görülmektedir. Nicel araştırma yönteminin kullanıldığ 1 tezlerde veri toplama aracı olarak anket kullanıldığı tespit edilmiştir. Demografik bilgiler ve ölçekler kullanıldığı belirtilen tezlerde veri toplma aracı anket kategorisinde sınıflandırılarak değerlendirme yapılmıştır. Karma yöntemin kullanıldığı araştırmalarda birden çok veri toplama aracı kullanıldığı görülmekte olup görüşme ve anket olarak karşımıza çıkmaktadır. Derleme kategorisinde sınıflandırılan tezlerde ikincil verilerden faydalanıldı̆̆ı görülmekte olup veri toplama aracı olarak ikincil veriler kategorisinde değerlendirme yapılmıştır. Bu sınıflandırma ve değerlendirmeler sonucunda 59 (\% 84,3) adet tezde anket kullanıldı̆̆ı, 4 (\% 5,7) adet tezde görüşme, 1 (\%1,4) adet tezde görüşme ve anket bir arada kullanılırken $6(\%$,6) adet tezde ikincil veriler, veri toplama aracı olarak kullanılmıştır. 
Tablo 4. Tezlerin Ana Bilim Dallarına Göre Dağılımı

\begin{tabular}{|c|c|c|}
\hline Tezlerin yayınlandığı ana bilim dalları & Frekans & Yüzde \\
\hline İşletme Ana Bilim Dalı & 25 & 35,71 \\
\hline Çalışma Ekonomisi ve Endüstri İlişkileri Ana Bilim Dalı & 13 & 18,57 \\
\hline Turizm İşletmeciliği Ana Bilim Dalı & 5 & 7,14 \\
\hline İnsan Kaynakları Yönetimi Ana Bilim Dalı & 4 & 5,71 \\
\hline Eğitim Bilimleri Ana Bilim Dalı & 4 & 5,71 \\
\hline Psikoloji Ana Bilim Dalı & 2 & 2,86 \\
\hline Beden Eğitimi ve Spor Ana Bilim Dalı & 2 & 2,86 \\
\hline Toplam Kalite Yönetimi Ana Bilim Dalı & 1 & 1,43 \\
\hline Sosyal Araştırma Yöntemleri & 1 & 1,43 \\
\hline Turizm Rehberliği Ana Bilim Dalı & 1 & 1,43 \\
\hline Eğitim Yönetimi ve Denetimi Ana Bilim Dalı & 1 & 1,43 \\
\hline Sosyal Hizmet Ana Bilim Dalı & 1 & 1,43 \\
\hline Spor Yöneticiliği Ana Bilim Dalı & 1 & 1,43 \\
\hline Psikiyatri Hemşireliği Ana Bilim Dalı & 1 & 1,43 \\
\hline İşletme Yüksek lisans Programı & 1 & 1,43 \\
\hline MBA Yüksek lisans Programı & 1 & 1,43 \\
\hline Girişimcilik ve İnovasyon Yönetimi Ana Bilim Dalı & 1 & 1,43 \\
\hline Hizmet Tasarımı ve İşletmeciliği Ana Bilim Dalı & 1 & 1,43 \\
\hline Eğitim Yönetimi ve Planlaması Ana Bilim Dalı & 1 & 1,43 \\
\hline Çalışma Ekonomisi Ana Bilim Dalı & 1 & 1,43 \\
\hline Turizm İşletmeciliği ve Otelcilik Ana Bilim Dalı & 1 & 1,43 \\
\hline Eğitim Yönetimi ve Politikası Ana Bilim Dalı & 1 & 1,43 \\
\hline TOPLAM & 70 & 100 \\
\hline
\end{tabular}

Tablo 4' de iş yaşam dengesi terimiyle taranarak ulaşılan lisansütü tezlerin ana bilim dallarına göre dağılımı incelendiğinde işletme ana bilim dalı 25 adet (\% 35,71) ile ilk sırada yer almaktadır. Çalışma ekonomisi ve endüstri ilişkileri ana bilim dalı 13 adet (\% 18,57) ikinci sırada, turizm işletmeciliği ana bilim dalı 5 adet tez (\% 7,14 ) ile üçüncü sırada yer almaktadır. Bu ana bilim dallarını insan kaynakları yönetimi ana bilim dalı, eğitim bilimleri ana bilim dalı, psikoloji ana bilim dalı, beden eğitimi ve spor ana bilim dalı takip etmektedir. Bu ana bilim dalları dışındaki diğer ana bilim dalları ise 1 er adet tez ile sıralamada yer almaktadır.

Ayrıca tezlerde danışman ünvanlarına göre yapılan incelemede ilk sırada 27 adet lisansüstü tezde $(\% 38,6)$ Doç.Dr ünvanı ilk sırada yer alırken, ikinci sırada Dr.Öğr.Üyesi 21 adet tezde (\% 30) ve üçüncü sırada Prof.Dr. ünvanı 20 adet tezde $(\% 28,6)$ yer almaktadır. Bu noktadan hareketle farklı ünvanlara sahip, farklı ana bilim dallarındaki danışmanların ve öğrencilerin iş yaşam dengesi konusuna ilgi duyduğu söylenebilir.

Aşağıda iş yaşam dengesi terimi ile Ulusal Tez Merkezi internet sitesinde taranan lisansüstü tezlerin yıllara ve türlerine göre dağılımı çapraz tablolar ile analiz edilmiş olup Grafik 1'de sunulmuştur. 


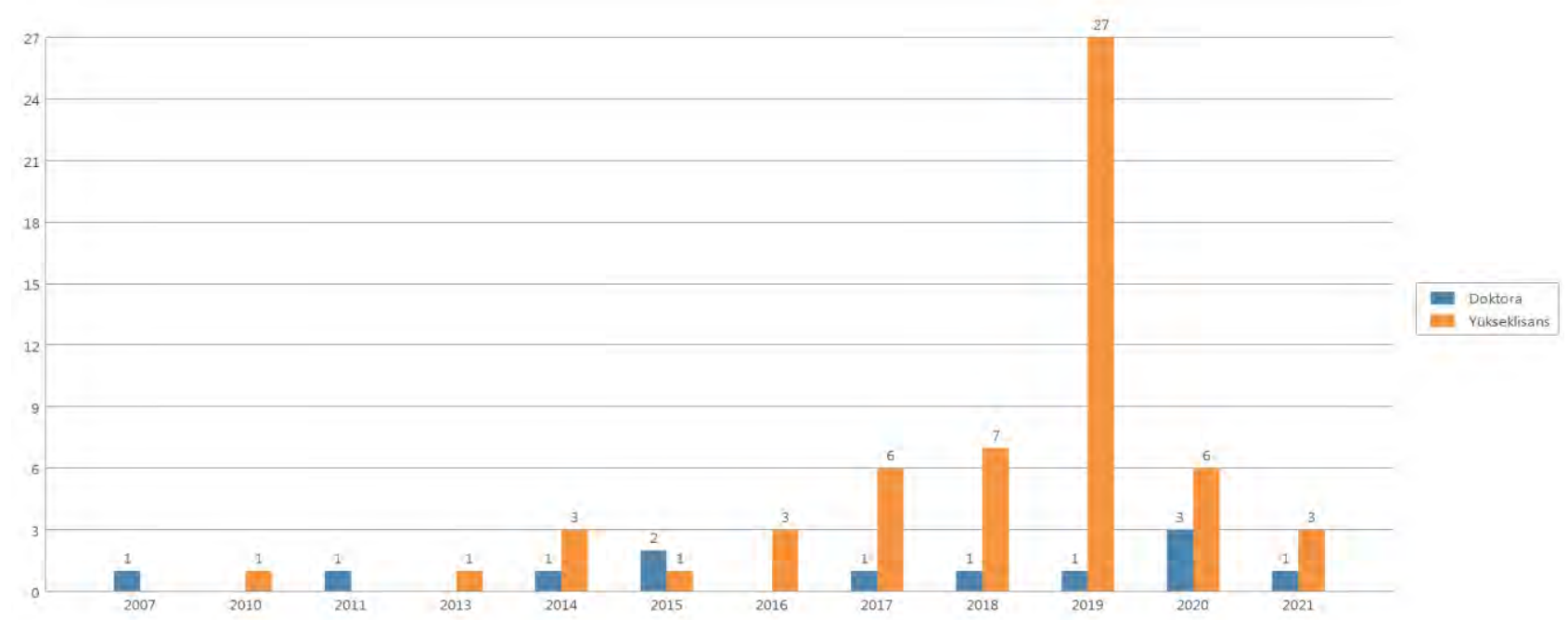

Grafik 1. Tezlerin Yıl ve Türlerine Göre Dağılımı

Grafik 1'de görüldüğü üzere 70 adet tezin 58 (\% 82,9) adeti yüksek lisans tezi olup $12(\% 12,1)$ adeti ise doktora tezidir. En çok 2019 yılında tez yayınlanmış olup 28 (\% 40) adet tezin 27 (\% 38,6)'si yüksek lisans tezi, 1 (\% 1,4) adeti ise doktora tezidir. 2007 yılında sadece $1(\%$ 1,4) adet tez yayınlanmış olup doktora tezidir.

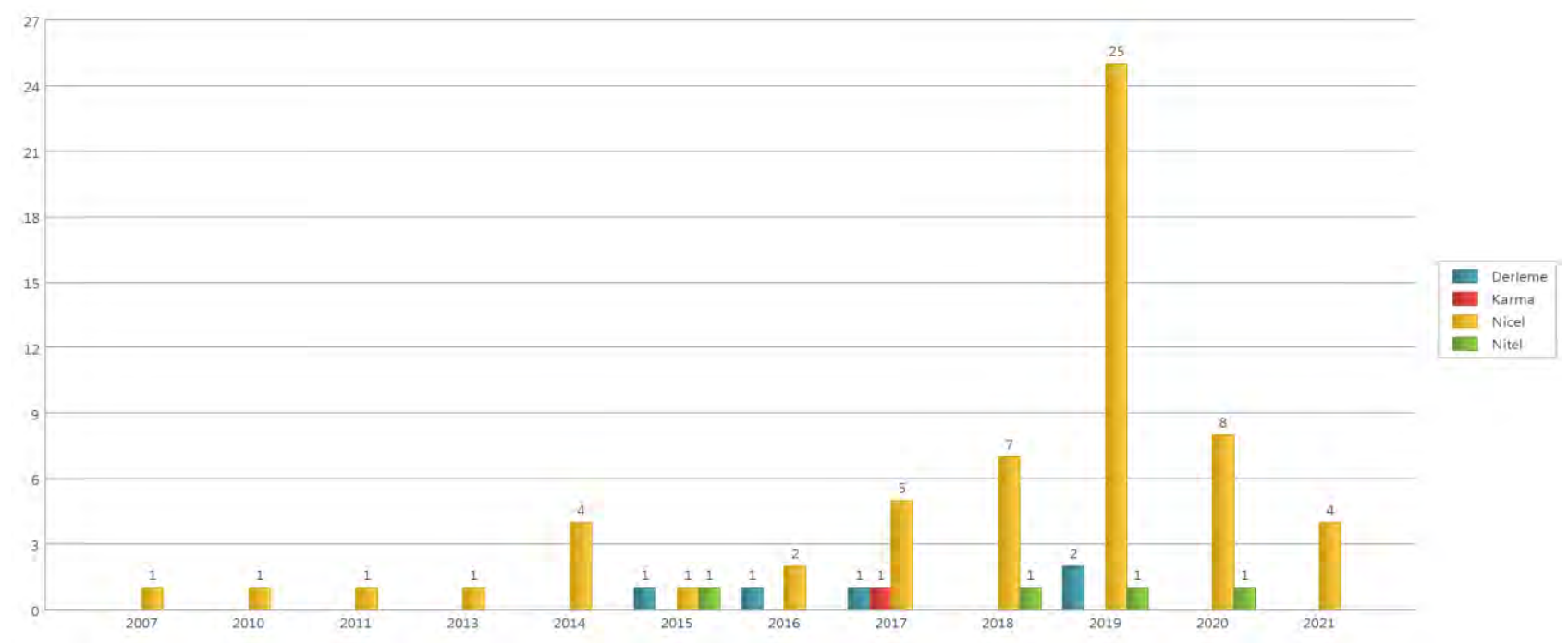

Grafik 2. Tezlerin Yıl ve Araştırma Yöntemlerine Göre Dağılımı

Lisansüstü tezlerin yıllara ve araştırma yöntemlerine göre dağılımı çapraz tablolar ile analiz edilmiştir. Araştırma yöntemleri nicel, nitel, karma ve derleme olarak sınıflandırılmıştır. Araştırma yöntemi bu kategoriler içerisinde doğrudan belirtilmeyen tezlerde sadece anket uygulanan, kişisel bilgi formu ve ölçek kullanıldığ $ı$ belirtilen tezler nicel kategoride değerlendirilirken, ikincil veriler taranarak yapılan tezler derleme kategorisinde, hem nicel hem nitel yöntem kullanılan tezlerde araştırma yöntemi karma yöntem olarak değerlendirilmiştir. Lisansüstü tezlerin 58 adeti yüksek lisans ve 12 adeti doktora tezidir. Toplamda 70 adet incelenen tez içerisinde, 60 (\% 85,7) adetinde nicel araştırma yöntemi kullanılmıştır. Ayrıca $5(\% 7,1)$ adet tezde derleme, 4 (\% 5,7) adet tezde nitel araştırma yöntemi, $1(\% 1,4)$ adet tezde karma yöntem kullanılmıştır. 2019 yılında en çok tez üretilmiş olup, 28 adet tezin 25 (\% 35,7) adetinde nicel araştırma yöntemi, 2 (\% 2.9) adetinde derleme, $1(\%$ 1,4) adetinde nitel araştırma yöntemi kullanılmıştır.

Dökümanlar incelenirken öncelikle tez başlıkları, anahtar kelimeler ve tez özetleri incelenerek en sık kullanılan kelime ve kavramların vurgulanması amaçlanmıştır. MAXQDA 2020 programında yer alan kelime sayımı işlevi ile öncelikle tez başlıklarına ait kelime frekansları ortaya konulmuştur. Kelime kökleri aynı olan kelimeler ekleri hariç tutularak birleştirme yoluna gidilmiştir. Bu bağlamda lisansüstü tezlerde iş yaşam 
dengesi konusu ile ilişkilendirilen diğer kavram ve ana konular da ortaya konulmuştur. Tez başlıkları değişkeni baz alınarak yapılan kelime frekansı analizi aşağıda Şekil 1'de yer almaktadır.

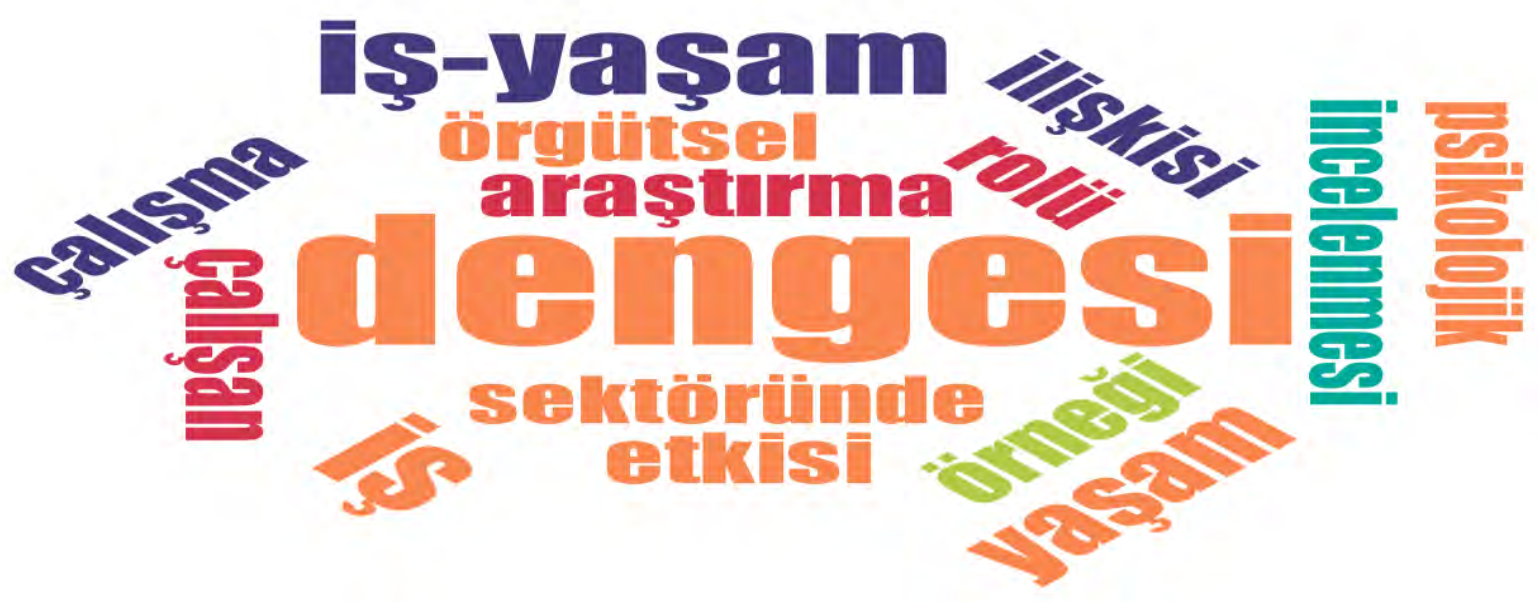

Şekil 1. Tez Başlıklarına Göre Kelime Frekansı

Öncelikle Şekil 1'deki kelime bulutunda da görüldüğü gibi kelime kökleri aynı olan kelimeler ekleri hariç tutularak birleştirilmiş ve 70 adet lisansüstü tezin, tez başlıklarında en sık rastlanan ilk üç kelime "dengesi (69 kere)", iş (44 kere) ve iş yaşam (41 kere)"'dır. Bu kelimelere ilaveten "yaşam, araştırma, etkisi, örneği, çalışan, ilişkisi, örgütsel, rolü ve çalışma" kelimelerinin takip ettiği görülmektedir.

Kelimelerin kullanım sıklığından da anlaşıldığı üzere iş yaşam dengesi farklı sektörlerde çalışanlar ve farklı örneklemler üzerinde ele alınırken, iş ve yaşam rolleri, örgütsel boyutu, farklı değişkenlerle ilişkisi ve etkileri üzerinde durulduğu görülmektedir.

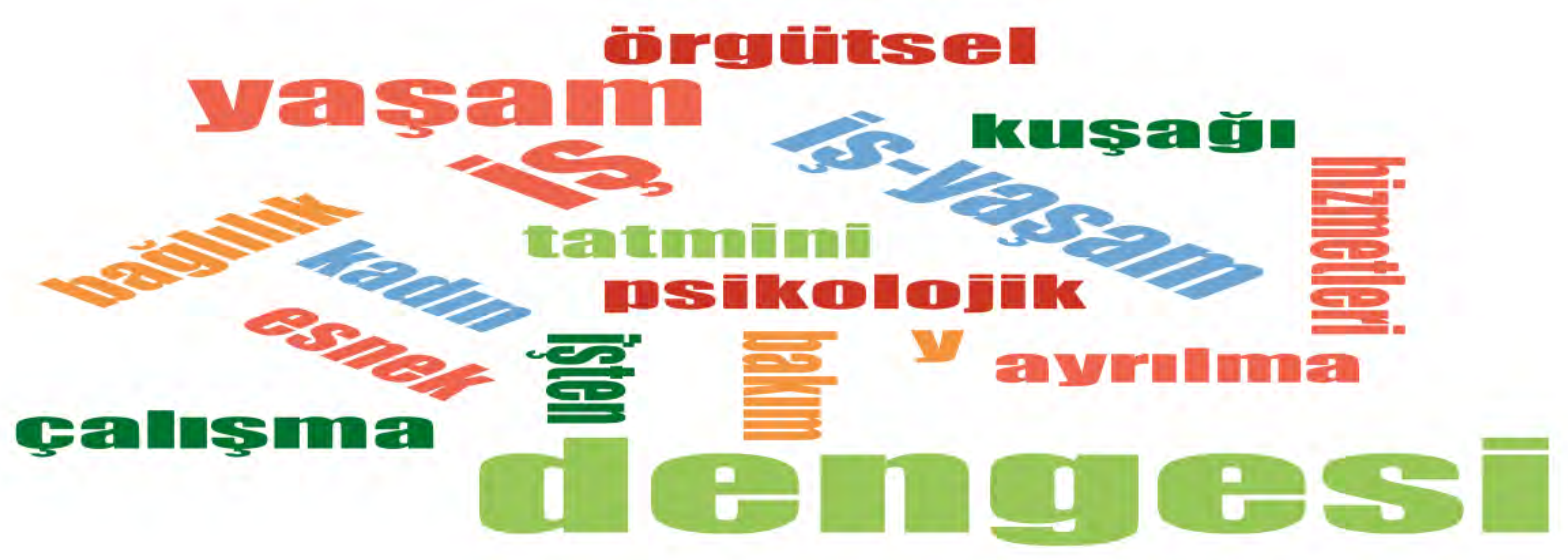

Şekil 2. Tezlerin Anahtar Kelimelerine Göre Kelime Frekansı

Şekil 2'de tüm tezlerdeki anahtar kelimeler incelenmiş, kelime kökleri aynı olan kelimeler ekleri hariç tutularak birleştirilmiş ve 70 adet lisansüstü tezin, anahtar kelimelerinde en sık rastlanan ilk üç kelime "dengesi (44 kere)", "iş (44 kere)" ve "iş yaşam (42 kere)" yer aldığ 1 görülmektedir. Ayrıca diğer en sık rastlanan kelimeler arasında "yaşam, araştırma, dengesinin, etkisi, örneği, örgütsel, rolü, çalışan ve çalışma" kelimelerinin yer aldığı görülmektedir. 


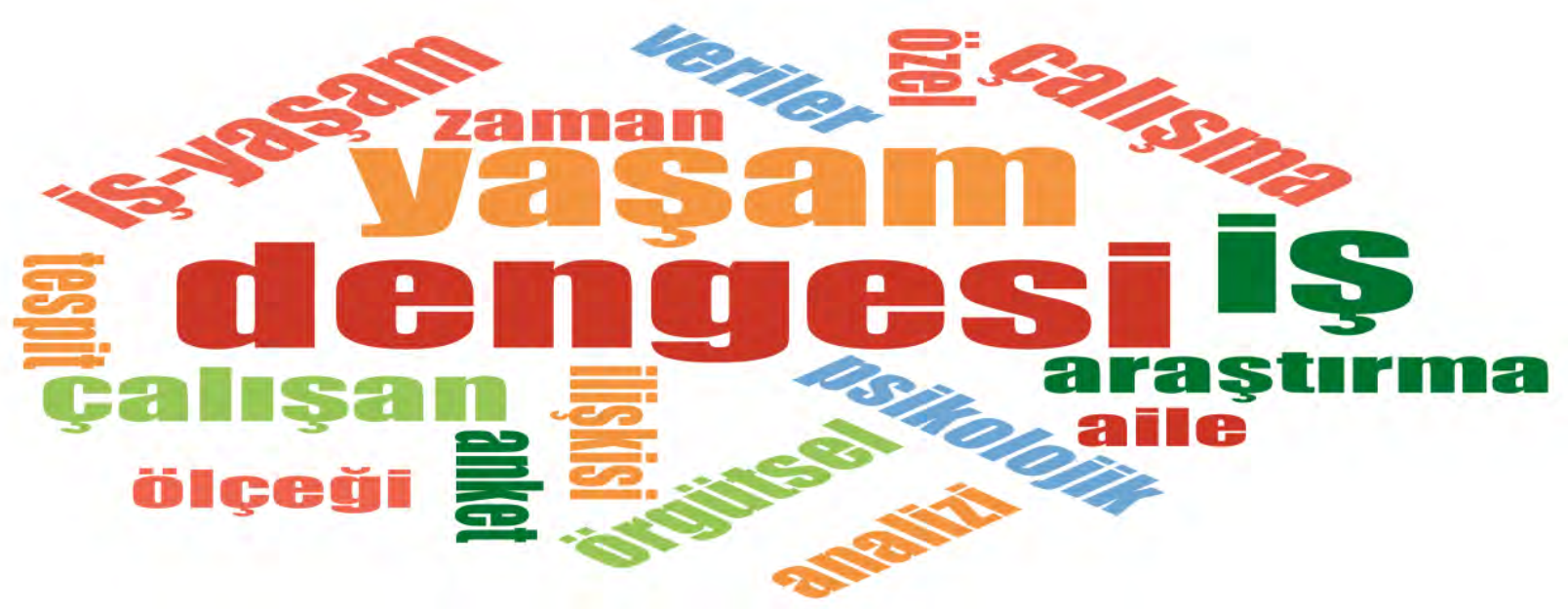

Şekil 3. Tez Özetleri Kelime Frekansı

Şekil 3'de tüm tezlerdeki özetler taranmış olup, kelime kökleri aynı olan kelimeler ekleri hariç tutularak birleştirilmiş ve 70 adet lisansüstü tezin, özetlerinde en sık rastlanan ilk üç kelime "dengesi (409 kere)", "iş (392 kere)" ve "yaşam (383 kere)" olarak karşımıza çıkmaktadır. Ayrıca "çalışan (220 kere)", "iş yaşam (207 kere), "çalışma (188 kere)", "araştırma (157 kere)", örgütsel (113 kere)", zaman (74 kere)" ve "ölçeği (69 kere)" kelimeleri kullanılmıştır. Yine "veriler, aile, anket, ilişkisi, psikolojik, tespit, özel ve analizi" kelimelerinin de sık geçtiği görülmektedir.

Tezlerin başlıkları, anahtar kelimeler ve özetler incelediğinde "denge, iş, iş yaşam, çalışan, çalışma, araştırma, örgütsel, zaman ve ölçek" gibi kelimelerin sıklığına daha fazla rastlanılmıştır. Araştırmalarda değişkenler arasındaki ilişkiler, etki ve aracılık rolü üzerinde durulduğu da görülmektedir. Tezlerde mobbing (psikolojik taciz), stres, iş stresi, kadın çalışanlar, zaman, girişimcilik, esnek çalışma, farklı çalışma biçimleri, işkoliklik, çalışan memnuniyeti, örgütsel bağlllık, tükenmişlik, pozitif psikoloji, psikolojik sermaye, iş tatmini, X, Y, Z kuşağı, işte var olmama sorunu, işten ayrılma eğilimi, örgütsel adalet, çalışan verimliliği, algılanan örgütsel destek kullanılan bazı değişkenler arasında yer almaktadır.

Araştırmaların özellikle farklı sektörlerde çalışanlar üzerine yoğunlaştığı görülmektedir. Örneklemler incelendiğinde kadınlar, kadın girişimciler, okul yöneticileri, öğretmenler, muhasebeciler, akademisyenler, $X$, Y, Z kuşağı çalışanları bazı örneklem çeşitleri arasında yer almaktadır.

\section{SONUÇ VE ÖNERİLER}

Araştırma sonucunda iş yaşam dengesinin birçok değişken ile ilişkisi, iş yaşam dengesinin diğer değişkenler üzerindeki etkisi, farklı değişkenlerin iş yaşam dengesi üzerindeki etkisinin özellikle farklı sektörlerde ve farklı örneklemlerde önemli olduğu görülmektedir. Araştırmada Yüksek Öğretim Kurumu Ulusal Tez Merkezinin internet sayfasından sadece iş yaşam dengesi terimiyle tarama yapılarak lisansüstü tezlere ulaşılmıştır. Araştırmaya konu olan tezlerin 2019 yılında yoğunlaştığı görülmektedir. Örgütlerde çalışma biçimlerinin farklılaşması, esnek çalışma, uzaktan çalışma gibi çalışma biçimlerinin daha fazla görülmesi iş yaşam profilinin değişmesine yol açmaktadır. Çalışanlar ve örgütler açısından iş yaşam dengesinin etkisinin ve sonuçlarının daha fazla araştırmalara konu olduğu düşünülmektedir. Ulaşılan lisansüstü tezlerin 2007'den itibaren daha fazla bu konuya yoğunlaşması yine son yıllarda çalışma yaşamının, farklı bir boyut kazanması ve yaşam içerisinde geniş bir alanı kaplamasından kaynaklandığı öngörülmektedir. Taranan tezlerin bir adetinin İngilizce, diğerlerinin Türkçe yazıldığı görülmektedir. Tezlerin daha çok işletme ana bilim dalında yazıldığı tespit edilmiştir.

Yurt içi ve yurt dışı literatürde makaleler, tezler ve çeşitli araştırma konularına yönelik benzer çalışmalar olduğu görülmektedir. Yurt içi literatüre (Kozak, 2000; Al ve Coştur, 2007; Tekindal vd., 2018; Ayaz ve Türkmen, 2018) ve yurt dışı literatüre (Angammana ve Jayatissa, 2016; Laudano vd., 2018; Donthu vd., 2020) yapılan çalışmalar örnek verilebilir. Örneğin Kozak (2000)'de yaptığı araştırmada, Türkiye'de akademik turizm literatürünün gelişimi ile ilgili, Türkiye' de bu alanda ulaşılan noktanın yadsınamayacak bir düzeyde olduğu, pek çok alanda en azından niceliksel olarak önemli mesafelerin kaydedildiğini tespit etmiştir. Al ve 
Coştur (2007)'un Türk Psikoloji Dergisi ve Türk Psikoloji Dergisi'ndeki makaleleri bibliyografik özellikleri açısından ele aldıkları araştırmada makalelerin neredeyse tamamının Türkçe olduğu ve dergide makale yayımlayan kişilerin en çok Hacettepe, Ankara ve Ortadoğu Teknik Üniversitesi'ndeki araştırmacılardan oluştuğu sonucu elde edilmiştir. Tekindal vd. (2018) yaptıkları araştırmada sosyal hizmet alanında yapılan lisansüstü çalışmaları incelemişler, tezlerin çoğunda nicel araştırma yöntemi kullanıldığı, tezlerin "aile, çocuk ve kadın" alanlarında yoğunlaşıldığı tespit etmişlerdir. Donthu vd. (2020) Journal of Bussiness Research dergisini bibliyometrik teknikleri kullanarak incelemiştir. Derginin etkisini, öne çıkan konularını, bağlı kuruluşları ve ülkeleri de dahil olmak üzere en üretken yazarlarını analiz etmişlerdir. Derginin pazarlama ve iş alanında saygın bir yere sahip olduğunu, akademik açıdan önemli konuları içerdiğini, birden fazla alanı kapsadığını ve sıklıkla takip edilen bir dergi olduğunu yaptıkları çalışma ile ortaya koymuşlardır.

İş yaşam dengesi ve iş yaşam dengesizliğinin, çalışanların hem iş yaşamı hem de diğer yaşam alanlarına olan artan etkisi bilinmektedir. İş yaşam dengesinin sağlanması çalışanları pozitif yönde etkilerken çalıştıkları örgütleri ve diğer yaşam alanlarını da (aile, özel, boş zaman gibi) pozitif olarak etkileyecektir. İş yaşam dengesinin geniş etkisi göz önüne alındığında birçok disiplinlerde araştırmaya konu olduğu ve olmaya devam edeceği görülmektedir. İş yaşam dengesinin birçok değişken ile çalışılması (verimlilik, iş tatmini, psikolojik taciz, stres, bağllık, çalışma biçimleri, işkoliklik, kuşaklar gibi) hem literatüre hem araştırmacı ve uygulayıcılara katkı sağlamaktadır. Farklı değişkenlerle farklı örneklem ve kültürlerde çalışılmasının daha fazla katkı sağlayacağı düşünülmektedir. Araştırmada tezlerde daha çok nicel yöntem kullanıldığı görülmüştür. Yapılacak tezlerde ileri düzey ve farklı nicel yöntemlerin, nitel ve karma yöntemin daha fazla kullanılması önerilmektedir. İş yaşam dengesi konusunun daha çok yüksek lisans tezlerinde ele alındığı görülmekte olup doktora tezlerine de yoğunlaşılmasının, daha farklı disiplinlerde çalışılmasının konunun öneminin daha çok anlaşılması ve etkisinin artması anlamında daha fazla katkı sağlayacağı düşünülmektedir. Konunun farklı değişkenlerle ele alınarak yeni tezler üretilmesi literatürdeki eksiklikleri giderecek ve sonuçları araştırmacılara, uygulayıcılara katkı sağlayacaktır. Ayrıca farklı konularda yapılan tezlerin, makalelerin bibliyometrik analiz yöntemiyle incelenmesi çalışmalar hakkında bilgi verirken alandaki çalışılmayan konular ve değişkenlerin ortaya konulmasını da sağlayabilecektir.

\section{KAYNAKÇA}

Al U. ve Coştur, R. (2007). Türk Psikoloji Dergisi'nin bibliyometrik profili. Türk Kütüphaneciliği, 21(2), 142-163.

Angammana, A. M. S. and Jayatissa, L. A. (2016). A Bibliometric Study of Postgraduate Theses in Library and Information Science with Special Reference to University of Kelaniya and University of Colombo, Sri Lanka

Ayaz. N. ve Türkmen, B. M. (2018). Yöresel yiyecekleri konu alan lisansüstü tezlerin bibliyometrik analizi. Gastroia: Journal of Gastronomy and Travel Research, 2(1), 22-38.

Brough, P., Timms, C., Chan, X. W., Hawkes, A. and Rasmussen, L. (2020). Work-life balance: definitions, causes, and consequences. Handbook of Socioeconomic Determinants of Occupational Health: From Macrolevel to Micro-level Evidence, 473-487.

Clark, S. C. (2000). Work/family border theory: A new theory of work/family balance. Human Relations, 53(6), 747-770.

De Bakker, F.G., Groenewegen, P. and Den Hond, F. (2005). A bibliometric analysis of 30 years of research and theory on corporate social responsibility and corporate social performance, Business $\mathcal{E}$ Society, 44(3), 283-317.

Delecta, P. (2011). Work life balance, International Journal of Current Research, 3(4), 186-189.

Dhas, M. D. B. and Karthikeyan, D. P. (2015). Work-life balance challenges and solutions: Overview. International Journal of Research in Humanities and Social Studies, 12 (2), 10-19, ISSN 2394-6288 (Print) \& ISSN 2394-6296 (Online)

Donthu, N., Kumar, S., and Pattnaik, D. (2020). Forty-five years of journal of business research: a bibliometric analysis, Journal of Business Research, 109, 1-14.

Guest, D.E. (2002). Perspevtives on the study of work-life balance, Social Sciences Information, 41 (2), 255-279. 
Gürbüz, S. ve Şahin, F.(2014). Sosyal Bilimlerde Araştırma Yöntemleri Felsefe-Yöntem-Analiz, Ankara, Seçkin Yayıncilık

Dolan, S., and Gosselin, E. (1998). Job satisfaction and life satisfaction: Analysis of a contingency model with social demographic moderators. Document de recherche, (98-02), 1-8.

Grzywacz, J. G., and Carlson, D. S. (2007). Conceptualizing work - family balance: Implications for practice and research. Advances in Developing Human Resources, 9(4), 455-471.

Hildebrandt, E. (2006). Balance between work and life-new corporate impositions through flexible working time or opportunity for time sovereignty? European Societies, 8 (2), 251-271.

Iverson, R. D., and Maguire, C. (2000). The relationship between job and life satisfaction: Evidence from a remote mining community. Human relations, 53(6), 807-839.

Kirchmeyer, C. (2000). Work-life İnitiatives: Greed Or Benevolence Regarding Workers' Time? In: Cooper CL, Rousseau DM (Ed.), Trends in Organizational Behavior: Time in Organizational Behavior, Wiley, Chichester, 7, 79-94.

Kozak, N. (2000). Türkiye'de akademik turizm literatürünün gelişim süreci üzerine bir inceleme, DAÜ: Turizm Araştırmaları Dergisi, 1 (1), 15-55.

Laudano, M. C., Marzi, G., and Caputo, A. (2018). A decade of the international journal of entrepreneurship and small business: A bibliometric analysis, International Journal of Entrepreneurship and Small Business, 33 (2), 289-314.

Lewis, S., Gambles, R., and Rapoport, R. (2007). The constraints of a 'work-life balance'approach: An international perspective, The International Journal of Human Resource Management, 18 (3), 360-373.

Lockwood, N. R. (2003). Work/life balance. Challenges and Solutions, SHRM Research, USA, 2-10.

O'Driscoll, M. (1996). The Interface between job and off-job roles: Enhencement and conflict in C. Cooper and I.Robertson (Ed.) International Review of Industrial and Organizational Psychology, Chichester:John Wily, 11, 279-306.

Rey-Martí, A., Ribeiro-Soriano, D., and Palacios-Marqués, D. (2016). A bibliometric analysis of social entrepreneurship, Journal of Business Research, 69 (5), 1651-1655.

Sok, J., Blomme, R., and Tromp, D. (2014). Positive and negative spillover from work to home: The role of organizational culture and supportive arrangements, British Journal of Management, 25(3), 456-472.

Syed, J. (2015). Work-life balance. In Syed, J. ve Özbilgin, M. (Ed.), Managing Diversity and Inclusion: An International Perspective, London: Sage, 291-314.

Tekindal, M., Özden, S. A. ve İçağasığlu, A. (2018). Systematic review on social work thesis in Turkey: 19872017, Journal of Current Researches on Health Sector (JoCReHeS), 8 (1), 41-50. 